\title{
Cooperative Learning Method and Development of Pre-School Children's Competences Acquisition in Mathematical Concepts in Kirinyaga County, Kenya
}

\author{
Kamau Bonface $^{1} \quad$ Prof J. C. Gatumu ${ }^{2} \quad$ Dr. E. Muriithi ${ }^{3} \quad$ Dr. R. Kahiga ${ }^{4}$ \\ School of Education, Mount Kenya University, P. O. Box, 342, Thika, Kenya
}

\begin{abstract}
The research from which this paper is derived explored the effect of cooperative learning method on development of pre-schoolers' competences in mathematical concepts. 20 pre-school teachers on their regular teaching in their pre-schools were observed teaching their 639 Pre-primary Two learners. The purpose of this study was to establish the difference between the mean score index of pre-school learners taught by a teacher who facilitates learning using the Cooperative Learning Method (CLM) and those taught by a teacher who does not. Data was collected through the use of observation schedule and teacher questionnaire. Each of the twenty pre-school teachers was observed by the researcher while facilitating mathematical concepts' competences during number work lessons. A documentary analysis guide was used to access the pre-school teachers' schemes of work and lesson plans to establish their level of preparation in line with CLM. Descriptive and inferential statistics were used to analyse the collected data and guided by the themes arising from the objective of the study the key findings were arrived at. The various levels of the teachers' facilitation of CLM were tied to the preschool leaners' performance in the mathematical concepts competences achievement test. The findings emerging showed that those learners who were taught using CLM achieved higher mean score indices than those who were not. The implication here is that the use of CLM improves pre-school learners' levels of achievement, indicating that it is a more effective method of teaching. Teachers' facilitation of CLM seemed to have a significant positive influence on the learners' Mathematical Concepts Competences Acquisition. These features were; availability of groupings and teacher preparedness, level of provision of learning resources, level of coordination, level of interaction, time taken in CLM activities. This implies that CLM imparts the required mathematical concepts competences better than traditional instructional methods. The study recommends that the Ministry of Education should develop programmes and policies that provide regular in-service training, in which CLM training forms a key part of the agenda and to refresh the mathematical concepts competences instructional skills of pre-school teachers.
\end{abstract}

Keywords: Competences; Cooperative Learning Method; Mathematical Concepts

DOI: $10.7176 / \mathrm{JEP} / 12-32-05$

Publication date: November $30^{\text {th }} 2021$

\subsection{Introduction}

One of the most vital aspects of pre-school education is the acquisition of mathematical concepts, as this equips learners with the skills required for developing logical thinking (Shinn, 2003). Mathematical concepts cover a wide range of aspects and are used in many fields. Singh, Granville and Dika (2012) posit that providing preschoolers with a solid base in core mathematical concepts is fundamental for progress in all areas of their education, as these underpin many aspects of learning and everyday life.

Furthermore, by acquiring mathematical concepts at an early stage, pre-schoolers increase their learning capabilities at later stages of life and are able to perform better as they progress through their education. Nevertheless, despite the importance attached to the learning of mathematical concepts, not just for education, but also for daily life, Fraser and Kahle (2014) observe a decline in learners' competences in these skills, and the decline in achievement in mathematical concepts among pre-school learners is of greatest concern.

Fraser and Kahle (2014) assert that many pre-school learners in places such as India lack core numeracy skills, such as counting, ordering and basic operations, which is often presented in their assessment. Rudhumbu (2014) found that learners in Zimbabwe often have limited ability in solving problems involving mathematical concepts, which is compounded in cases where pre-school teachers feel frustrated when endeavouring to address the needs of individual learners. In places such as South Africa, Tanzania and Uganda, as well as Kenya, Clindiebere (2013) found that pre-school learners lack competence in solving problems based on mathematical concepts due to the processes involved, often because many teachers still use teacher-centred methods that hinder the learning of mathematical concepts.

Kenya, and particularly Kirinyaga County, is no exception with regard to the decline in learner competences in mathematical concepts. In many parts of the country, extra-large class sizes, lack of suitable learning resources and adequate facilities are likely to influence the use of teacher-centred methods.

In line with this, Ngusa, Begi and Ndani (2018) advocate that teachers should introduce cooperative groups 
with pre-school learners to practise problem-solving strategies by manipulating materials in order to solve tasks based on mathematical concepts. It is against this backdrop and the urgent need to ensure that all pre-school learners in Kirinyaga County fully develop their comprehension and application of mathematical concepts that this assessment of the suitability of the Cooperative Learning Method (CLM) as an instructional technique has been undertaken.

\subsection{The Concept of the Cooperative Learning Method (CLM) in Pre-schools}

Alshammari (2015) defines the Cooperative Learning Method (CLM) as a teaching approach where small, manageable groups of pre-schoolers work together as a team on a common task, which can be as simple as solving a multi-step mathematical problem or as complex as developing a design for a new kind of school. Using CLM for mathematical activities, small groups of learners make use of a variety of criteria, such as social skills, academic skills, pre-school learner interests and instructional objectives, in order to work towards improving each individual's academic achievement in mathematical concepts. Felder and Brent (2012) highlight the fact that CLM makes use of the personal experiences of others in addition to those of the individual learner.

Angadi and Darga (2015) observe that although implementing full-scale CLM in pre-schools in Nigeria has not been a simple task, cooperative learning strategies give learners opportunities to do Mathematics by themselves, speak their thoughts, offer and receive explanations, introduce several procedures for solving mathematical problems and therefore enables them to profit from the mathematical knowledge available in the group as a whole.

Evidence also appears to indicate that CLM increases pre-school learners' self-esteem, motivation and empathy. Njoroge and Githua (2013) assert that the results of positive cooperative experiences lead to higher level thinking and analytical skills in mathematical concepts, greater attempts within the group at achieving successful working relationships, and enhanced psychological wellbeing. Furthermore, when pre-school learners notice the value of their input and effort in CLM, this fosters a more internal locus of control and belief in their own ability, in addition to the embedding of social and work skills.

\subsection{Mathematical Concepts Competence Acquisition (MCCA) and the Role of CLM in Pre-schools}

Chen and Li (2014) maintain that individuals display numerical competence almost from the day they are born and that, even when they were less than six months old, some individuals have shown they are able to perform a rudimentary kind of addition and subtraction. These abilities suggest that number is a fundamental component of the world that children know. Whether and how this early sensitivity to number affects later development in mathematical activities remains to be demonstrated, but it is evident that children enter the world prepared to notice number (including numerals) as a feature of their environment.

Mathematical concepts competences taught in pre-school are intended to provide the foundational learning that children need in order to thrive from their early years, through all levels of their education and beyond. At pre-school level, these concepts include number sense, learning of numbers through representation or pictures, counting, ordering, geometry and performance of basic operations, such as addition and subtraction. Anobile, Cicchini and Burr (2012) recommend that teachers ought to focus instruction in pre-school on the basic skills that underpin competence in mathematical concepts at primary, secondary and tertiary education settings, and that right from pre-school through elementary or primary school, learners should be preparing the groundwork for future life skills.

In many countries in Sub-Saharan Africa, mathematical concepts competences rank highly in comparison to other disciplines in pre-schools and any learner who manifests excellence in such skills is considered to have high levels of cognitive abilities. For example, in Nigeria, Ojedapo, Fazio, Bailey, Thompson and Siegler (2014) note that a pre-school learner who scores above $75 \%$ in any mathematical concepts test is considered to be excellent in mathematical concepts. However, despite these findings, Ojedapo et al. (2014) observe that many pre-school learners still lack competence in many mathematical concepts. Counting is one of the mathematical concepts where these learners exhibit poor skills.

In Kirinyaga County, as elsewhere, mathematical concepts competences acquisition (MCCA) is critical to every pre-school learner's success. However, in many instances, pre-school learners' competence in mathematical concepts is extremely low. Based on the recommendation made by Uwezo (2010), it is important that teachers should adopt teaching methods which are learner-centred. Research by Adams (2013) demonstrates an increase in academic achievement in learners who have acquired their subject knowledge through the use of CLM. However, the effectiveness of the key elements of CLM in enabling pre-school learners to achieve competence in mathematical concepts has yet to be fully examined and more still needs to be done to assess the level to which teachers' use of CLM influences pre-school learners' MCCA.

\subsection{Teacher Facilitation of CLM for MCCA in Pre-school Learners}

Pre-school teachers play an imperative facilitation function in CLM and many of them use it or use a group-work 
learning strategy to boost their learners' competences in basic numeracy concepts. Whether the aim is to boost pre-schoolers' understanding of learning content, to construct careful transferable skills, or a combination of both, teachers routinely turn to small group work to make the most of the returns of peer-to-peer teaching.

Johnson and Johnson (2014) note that this cooperative instructional group work involves pre-school learners working collectively to make the most effective use of their own and each other's learning to support mutual development. In other words, CLM requires positive interdependence, where pre-school learners observe that improved achievement by individual learners results in improved performance for the whole group (Johnson and Johnson, 2014). It can either be formal or informal, but regularly demands precise teacher involvement to take full advantage of pre-school learner interaction and mutual learning. This gives learners control over their learning and allows to learn at their pace.

In addition, Mentz et al. (2010) observe that ownership of teaching and learning is shared by groups of preschool learners, and is no longer the sole responsibility of the teacher but also of the learners. The authority of setting goals, assessing learning, and facilitating learning remains with the teacher, although it is shared by all. Slavin (2015) assertively notes that in classes in Mexico where learning takes place using CLM, ultimate responsibility for setting goals, facilitating and assessing learning still lies with the teacher.

Rudhumbu (2014) observes that teachers in Zimbabwe have adopted CLM to make teaching of mathematical concepts effective amongst pre-school learners and that in doing so, they have changed the focus of classrooms from being teacher-centred, where teachers impart knowledge to learners, to learner-centred where learners are expected to play a more active part in the process of their own knowledge construction. Mentz et al. (2010) also maintain that CLM changes pre-school learners' and teachers' roles in classrooms.

In keeping with these findings, Lou, Abrami, Spence, Poulsen, Chambers and d'Apollonia (2013) conducted a study in Austria which found that teachers using CLM continue to play an active role in the classroom while the groups work, by monitoring their work and evaluating group and individual performance. In addition, Lou et al (2013) demonstrated that teachers also give confidence to the groups of learners, which enables them to reflect on their interactions in such a way that they recognise potential improvements for future group work. Ngusa et al. (2018) found that teachers who use cooperative groups have their pre-school learners able to choose a set of criteria to classify mathematical properties, such as geometric figures, and then explain their criteria to other groups. This indicates that, due to the nature of CLM, the role of the teacher changes from instructing by providing information to their students to facilitating learning allowing students to develop greater autonomy and to become more independent learners.

However, despite the well-documented benefits of CLM in teaching mathematical activities in pre-schools, implementing this pedagogical practice in classrooms, or indeed any of the structured peer-mediation programs, in many countries in Sub-Saharan Africa is a challenge and many pre-school teachers find it difficult to accomplish (Adebayo, 2014). In Nigeria, for example, Kalawole (2007) asserts that difficulties may occur because elementary school teachers often do not have a clear understanding about how to establish effective cooperative groups, the research and theoretical perspectives that have informed this approach, and how they can translate this information into practical classroom applications as a strategy for improving academic achievement in mathematical activities among pre-school learners. This is indicative of the fact that embarking on CLM and conducting mathematical learning sessions demands a dedication to articulating the procedures specified in the curriculum and in implementing, monitoring and evaluating them.

According to Njoroge and Githua (2013), pre-school teachers have the task of providing a brief historical overview of the theoretical underpinnings of CLM and then highlighting the key role social interdependence plays in establishing a stable group structure that motivates all of the group members to work together, to build quality relationships and to actively support each other's learning. In Kenya, including in Kirinyaga County, preschool teachers play a vital function in enhancing the exchange of ideas by pre-school learners, as well as encouraging them in the learning progress.

Nevertheless, from the research that has been undertaken to date, there is a lack of information about preschool teachers' verbal behaviours when they use CLM in the classroom and the degree to which they use CLM in order to increase pre-school learners' competence in basic numeracy skills and Ngusa et al., (2018) note that further research is required to identify the degree to which teachers' use of CLM influences MCCA in pre-school learners. Furthermore, none of the empirical studies to date indicate how pre-school teachers can promote discussion of mathematical concepts competences among their pre-school learners and how, in turn, their preschool learners can help each other.

The above review of related literature highlights research that shows an increase in academic achievement through the use of CLM. However, the effectiveness of its key elements in enabling pre-school learners to achieve competence in mathematical concepts has yet to be fully examined and more still needs to be done to assess the level to which teachers' use of CLM influences pre-school learners' MCCA.

The above review of related literature also identifies the current lack of information about a) the extent to which teachers use CLM in order to increase pre-school learners' competence in basic numeracy skills and how 
teachers' use of CLM influences MCCA in pre-school learners; b) teachers' verbal behaviours when using CLM; c) how pre-school teachers can promote discussion of mathematical concepts competences among pre-school learners; and d) how pre-school learners can assist each other in learning during classes using CLM.

\subsection{Research Methodology}

This study made use of correlational and comparative research designs, employing qualitative and the quantitative Approach that helped in determining the existing differences in the acquisition of mathematical concepts competences among pre-school learners and in establishing the relationships between the variables when using the CLM in comparison with traditional teaching methods without manipulating the variables. A sample of twenty out of one hundred and ninety seven pre-schools, their (twenty) pre-school teachers and 639 pre-school learners were used. This exercise took place in one academic calendar term of teaching in 2019.

Each of the teacher's documents and live lessons were observed using agreed criteria of the elements specified for facilitating CLM appropriately (Johnson, D. W., \& Johnson, R. T., 2009). The researcher used a documentary analysis guide to establish adherence to the aspects of the schemes of work and lesson plans with a focus on the five elements of CLM postulated by Johnson, D. W., \& Johnson, R. T. (2009). The concern was whether any of these documents had factored in the five elements of CLM which should form the planning for teaching. From the scheme of work and the lesson plan, the points of focus were the CLM elements; availability of groupings and teacher preparedness, level of provision of learning resources, level of coordination, level of interaction and time taken in CLM activities. The researcher would record the different elements of CLM for the specific lesson plan derived from the scheme of work. Documentary analysis was derived from the model of Bowen, 2009. This involved examining relevant professional documents: schemes of work, lesson plans and lesson notes for the previous term (a total of 60 lessons). The researcher calculated the weighted frequencies of the teachers' preparation of the documents, according to the number of times there was evidence of preparation, as: 0-20 times: Low level preparation; 21-40 times: Mid-level preparation; 41-60 times: High level preparation.

It was after the data collection using documentary analysis guide, teacher's questionnaire and mathematical concepts competences achievement test that the researcher proceeded to observe life lessons in real-life learning situation. The concern here was to assess how the various elements of CLM were emerging in the various parts of the learning session: lesson introduction, development and conclusion. The researcher used observation schedule to collect this data. During the observation the researcher noted the extent to which pre-school teachers appropriately undertook the activities specified for using CLM during learning.

Responses to the themes in the research question items related to CLM facilitation in the observation schedule were assigned numerical codes. This made it quantifiable so that the data could be keyed into the SPSS spread sheet for analysis. Computation of the aggregate points of the various themes relating to the CLM facilitation-oriented research question items as per the numeral codes assigned by the researcher was done. The total aggregate points ranged between 95.00 and 168.00 . The $75^{\text {th }}$ percentile was determined as the cut-off point for identifying learners who were taught using CLM. Pre-school learners who were above the cut-off point were deemed to have been taught mathematical concepts competences using CLM, whereas those whose aggregate points were below the 132 points cut-off were categorised as having not been taught mathematical concepts competences using CLM. This status was used to compare the mean score indices across the two categories of learners using cross tabulations, descriptive statistics and the T-test.

The MCCAT determined the pre-school learners' level of achievement in mathematical concepts competences. The scores were pegged on a learner's level of attainment of the mathematical concept problems they solved. This is after marking each of the 639 pre-school learner's MCCAT script and calculating their mean score. It was marked out of 20 , for which each of the five topic areas (number recognition, number patterns, number values, addition and subtraction) had a maximum of 4 (four) marks.

With reference to the qualitative grading system specified by Kenya's Competence-Based Curriculum $(\mathrm{CBC})$, the rubric for the mean scoring was as follows: Below Expectation, Approaching Expectation, Meeting Expectation and Exceeding Expectation. The researcher assigned numerals to the grading in order to make it quantitative for the purpose of data analysis and gave a weighting of the scale;

A score of 3-4: Exceeding Expectation.

Scores of 2-3: $\quad$ Meeting Expectation and

A score of 1-2: Approaching Expectation,

A score of 0-1: Below Expectation,

The qualitative and the quantitative data from the research tools was analysed; with the learner being the unit of analysis. 


\subsection{Research Findings and Discussions}

4.1 Availability of Learning Groups and Learners' MCCA

Table 1 shows data on availability of learning groups and learners' MCCA.

Table 1: Availability of Learning Groups and Learners' MCCA

\begin{tabular}{|c|c|c|c|c|c|}
\hline \multirow[t]{3}{*}{ Status } & \multirow{2}{*}{$\begin{array}{c}\text { No of } \\
\text { teachers }\end{array}$} & \multicolumn{4}{|c|}{ Pre-school learners' MCCA } \\
\hline & & $\begin{array}{c}\text { Below } \\
\text { Expectation }\end{array}$ & \multirow{2}{*}{$\begin{array}{l}\begin{array}{l}\text { Approaching } \\
\text { Expectation }\end{array} \\
\mathrm{n}=40\end{array}$} & \multirow{2}{*}{$\begin{array}{c}\begin{array}{c}\text { Meeting } \\
\text { Expectation }\end{array} \\
\mathrm{n}=171\end{array}$} & \multirow{2}{*}{$\begin{array}{r}\begin{array}{c}\text { Exceeding } \\
\text { Expectation }\end{array} \\
\mathrm{n}=424\end{array}$} \\
\hline & $\mathrm{N}=20$ & $\mathrm{n}=4$ & & & \\
\hline \multicolumn{6}{|c|}{ Whether the teacher established CLM groups } \\
\hline Established & $85 \%$ & $0 \%$ & $9 \%$ & $18 \%$ & $73 \%$ \\
\hline \multirow[t]{2}{*}{ Not established } & $15 \%$ & $2 \%$ & $5 \%$ & $33 \%$ & $63 \%$ \\
\hline & $\mathrm{N}=20$ & $\mathrm{n}=7$ & $\mathrm{n}=73$ & $\mathrm{n}=217$ & $\mathrm{n}=342$ \\
\hline \multicolumn{6}{|c|}{ Groups working in an organised, sequential way } \\
\hline Yes & $100 \%$ & $1 \%$ & $11 \%$ & $34 \%$ & $54 \%$ \\
\hline No & $0 \%$ & $0 \%$ & $0 \%$ & $0 \%$ & $0 \%$ \\
\hline
\end{tabular}

According to Table1, learner achievement increases consecutively, starting from Below Expectation, Approaching Expectation, Meeting Expectation, right up to Exceeding Expectation at 0\%, 9\%, 18\% and 73\%. This trend is similar for learners who were not organised in learning groups at 2\%, 5\%, 33\% and $63 \%$ consecutively. There was a significant difference between the two groups, where the latter performed relatively lower.

Linked to these findings, Table 2, which presents information gathered through the questionnaire about teachers' views on the frequency of CLM group formation and learners' MCCA, reveals that the learners organised in groups always achieved scores at the higher end of the grading system. This appears to confirm the assertion that the use of group work is fundamental in enhancing pre-school learners' educational achievement in basic numeracy concepts (Huber, 2006).

From the evidence, all of the learning groups were working in an organised way during the learning session, with just over half of the learners (54\%) Exceeding Expectation. It would appear from this that members of cooperative groups use higher level reasoning strategies more frequently than when individuals work by themselves.

Using the documentary analysis guide, data was gathered from teachers' professional records, more specifically, their schemes of work and lesson plans, about how they documented evidence of their use of CLM groups as the means to organise learning (one of the key aspects of CLM) in teaching mathematical concepts competences. Levels of organisation for learning were determined by what was documented in the schemes of work and lesson plans. The data collected related to how often pre-school teachers used CLM and was used to identify how the use of CLM or otherwise had an impact on learner achievement. This information is presented in Table 2.

Table 2: Documentary Evidence of Learning Group Formation and Learners' MCCA

\begin{tabular}{|c|c|c|c|c|c|c|}
\hline \multirow[t]{3}{*}{ Status } & \multirow{2}{*}{$\begin{array}{c}\text { No of } \\
\text { teachers }\end{array}$} & \multicolumn{5}{|c|}{ Pre-school learners' MCCA } \\
\hline & & $\begin{array}{c}\text { Below } \\
\text { Expectation }\end{array}$ & $\begin{array}{l}\text { Approaching } \\
\text { Expectation }\end{array}$ & $\begin{array}{c}\text { Meeting } \\
\text { Expectation }\end{array}$ & $\begin{array}{l}\text { Exceeding } \\
\text { Expectation }\end{array}$ & $\begin{array}{c}\text { Status } \\
\%\end{array}$ \\
\hline & $\mathrm{N}=20$ & $n=7$ & $\mathrm{n}=73$ & $\mathrm{n}=217$ & $\mathrm{n}=342$ & $\mathrm{~N}=639$ \\
\hline \multicolumn{7}{|c|}{ teacher's frequency of forming learning groups } \\
\hline \multirow[t]{4}{*}{ t indicated } & $70 \%$ & $1 \%$ & $10 \%$ & $24 \%$ & $65 \%$ & $53 \%$ \\
\hline & $0 \%$ & $0 \%$ & $27 \%$ & $73 \%$ & $0 \%$ & $3 \%$ \\
\hline & $25 \%$ & $1 \%$ & $9 \%$ & $45 \%$ & $46 \%$ & $26 \%$ \\
\hline & $5 \%$ & $4 \%$ & $17 \%$ & $39 \%$ & $40 \%$ & $18 \%$ \\
\hline
\end{tabular}

Table 2 indicates that the majority of learners $(65 \%)$ who were never organised in CLM groups (or whose teachers never indicated that they did) Exceeded expectation; $73 \%$ of those rarely taught in CLM groups just Met expectation; $46 \%$ of those often taught in CLM groups Exceeded Expectation and $40 \%$ of those very often taught in CLM Exceeded Expectation. For learner grouping, Table 3 illustrates that just over half of the learners (53\%) were either never taught in CLM groups or their teachers did not indicate whether they were ever organised in CLM groups during learning. According to the information obtained, teachers of a quarter of the learners $(26 \%)$ indicated that they often used CLM groups, $18 \%$ stated that they used GLM groups very often and 3\% said that they rarely used CLM groups.

Although the Expectation is that learners whose teachers established CLM groups very often would achieve the highest level of performance, from the evidence, they were actually below the mean average across the grades. This implies that some teachers may be more efficient in their documentation for planning and preparation, but not necessarily able to implement it in practice. The reasons for this are likely to vary, although 
it may be due to the demanding nature of the CLM lesson implementation process or failure to comprehend exactly what they are required to do in order to complete all documentation successfully.

Data was also collected on teachers' understanding of CLM, whether they used it and how often they had their learners form CLM groups to make learning of mathematical concepts competences easier and enjoyable, as presented in Table 3 .

Table 3: Teachers' Views on CLM Group Formation Frequency and Learners' MCCA

\begin{tabular}{|c|c|c|c|c|c|c|}
\hline \multirow{3}{*}{ Status } & \multirow{2}{*}{$\begin{array}{l}\text { No of } \\
\text { teachers }\end{array}$} & \multicolumn{5}{|c|}{ Pre-school learners' MCCA } \\
\hline & & $\begin{array}{c}\text { Below } \\
\text { Expectation }\end{array}$ & $\begin{array}{l}\text { Approaching } \\
\text { Expectation }\end{array}$ & $\begin{array}{c}\text { Meeting } \\
\text { Expectation }\end{array}$ & $\begin{array}{c}\text { Exceeding } \\
\text { Expectation }\end{array}$ & $\begin{array}{c}\text { Status } \\
\%\end{array}$ \\
\hline & $\mathrm{N}=20$ & $\mathrm{n}=7$ & $\mathrm{n}=73$ & $\mathrm{n}=217$ & $\mathrm{n}=342$ & $\mathrm{~N}=639$ \\
\hline \multicolumn{7}{|c|}{ Understanding of CLM } \\
\hline Yes & $95 \%$ & $1 \%$ & $11 \%$ & $33 \%$ & $55 \%$ & $97 \%$ \\
\hline No & $5 \%$ & $0 \%$ & $27 \%$ & $72 \%$ & $0 \%$ & $3 \%$ \\
\hline \multicolumn{7}{|l|}{ Use of CLM } \\
\hline Yes & $90 \%$ & $1 \%$ & $12 \%$ & $36 \%$ & $50 \%$ & $90 \%$ \\
\hline No & $10 \%$ & $0 \%$ & $3 \%$ & $13 \%$ & $84 \%$ & $10 \%$ \\
\hline \multicolumn{7}{|c|}{ Frequency in the use of CLM } \\
\hline Never & $35 \%$ & $0 \%$ & $0 \%$ & $0 \%$ & $0 \%$ & $0 \%$ \\
\hline Rarely & $60 \%$ & $0 \%$ & $0 \%$ & $0 \%$ & $0 \%$ & $0 \%$ \\
\hline Often & $5 \%$ & $0 \%$ & $10 \%$ & $20 \%$ & $70 \%$ & $3 \%$ \\
\hline Very Often & $0 \%$ & $1 \%$ & $12 \%$ & $34 \%$ & $53 \%$ & $95 \%$ \\
\hline \multicolumn{7}{|c|}{ Forming of CLM groups } \\
\hline Never & $30 \%$ & $0 \%$ & $0 \%$ & $0 \%$ & $0 \%$ & $0 \%$ \\
\hline Rarely & $55 \%$ & $0 \%$ & $0 \%$ & $0 \%$ & $0 \%$ & $0 \%$ \\
\hline Often & $10 \%$ & $0 \%$ & $13 \%$ & $30 \%$ & $57 \%$ & $10 \%$ \\
\hline Very Often & $5 \%$ & $1 \%$ & $11 \%$ & $34 \%$ & $53 \%$ & $91 \%$ \\
\hline \multicolumn{7}{|c|}{ Forming CLM groups makes teaching easier and enjoyable } \\
\hline Strongly Disagree & $5 \%$ & $0 \%$ & $0 \%$ & $0 \%$ & $0 \%$ & $0 \%$ \\
\hline Disagree & $10 \%$ & $0 \%$ & $15 \%$ & $34 \%$ & $51 \%$ & $6 \%$ \\
\hline Undecided & $10 \%$ & $0 \%$ & $0 \%$ & $0 \%$ & $0 \%$ & $0 \%$ \\
\hline Agree & $20 \%$ & $2 \%$ & $13 \%$ & $40 \%$ & $45 \%$ & $51 \%$ \\
\hline ongl & $60 \%$ & $1 \%$ & $9 \%$ & $27 \%$ & $64 \%$ & \\
\hline
\end{tabular}

As shown in Table 3, the vast majority of learners (97\%) were said to have been taught by teachers who understand CLM as an instructional method for MCCA and $90 \%$ were said to have been taught using CLM. A total of $95 \%$ of learners were indicated to have been taught using CLM at a frequency classed as very often, whereas $91 \%$ of them were said to be taught in CLM organised groups.

Nevertheless, there was a significant disparity between these figures and what the researcher witnessed during observations, which would then partially concur with the notion that, despite a theoretical interest in team learning and many teachers' generally high appreciation of CLM as a didactic method, cooperative learning is a rare event in the average classroom (Rotering-Steinberg, 2000). It is possible that this may result from an unfavourable view which some teachers may have of CLM.

However, whereas the majority of learners $(55 \%)$ taught by teachers who said that they understood CLM Exceeded Expectation, of those learners taught by teachers who did not understand CLM, 72\% only Met Expectation; interestingly, none of these learners achieved either Below Expectation or Exceeded Expectation.

Surprisingly, just over half (50\%) of the learners indicated as being taught using CLM Exceeded Expectation, which was actually a level of achievement below those learners indicated as not taught using CLM (84\%). This would be attributable to the small population of learners in that category who were indicated not to have been taught using CLM.

Nevertheless, other forms of learning group organisation were observed in the classroom, including:

A Whole class group organisation, learners working in pairs, learners working in groups of three, learners working individually. In other cases, the group element featured only when responding to the teacher's questions orally during learning. There were cases where the whole class group of learners would crowd around the teacher at the blackboard for the whole lesson. This demonstrates some teachers' unwillingness to practise CLM facilitation and a tendency to stick to traditional methods of teaching.

Therefore, there is also the possibility that some teachers did not indicate the true position and that they may not be using CLM in their facilitation of mathematical concepts competences, or they may assume that they know what CLM entails, but do not have the necessary support to put it into practice.

From the above, it would appear that teachers are likely to benefit from being provided with additional time 
for planning and consulting others regarding the most effective ways to enable their learners to increase their acquisition of competence in mathematical concepts, with appropriate support and guidance to be able to practise CLM.

Learners taught by teachers who use CLM often and very often Exceeded Expectation at 70\% and 53\% respectively. Those taught by teachers who form CLM groups often and very often achieved at $57 \%$ and $53 \%$ respectively. One would have expected the reverse to be the case, especially with the fact that there were more learners who were Below Expectation and Approaching Expectation among the learners taught by teachers who gave the impression that they use CLM as an instructional method very often and also form CLM groups very often.

In a statement on whether teachers helped their learners to form CLM groups to make the learning of mathematical concepts easier and enjoyable, 51\% of teachers agreed, 43\% strongly agreed and $6 \%$ disagreed. The highest percentage of learners who Exceeded Expectation were those who were taught by teachers who strongly agreed that they helped their learners to form CLM groups. 51\% of learners who Exceeded Expectation were taught by those who strongly disagreed and $45 \%$ by those who agreed. This information did not match what a number of teachers had indicated in the previous question.

According to the responses given, none of the learners were taught by teachers who never formed CLM groups. In contrast, $6 \%$ of the learners were taught by teachers who disagreed that they helped learners to form CLM groups. This implies that although some teachers never apply CLM in their teaching, they know it is a better method of instruction than the traditional ones. The teachers may be resisting a change from using traditional teaching methods to using CLM as a means to facilitate acquisition of competence in mathematical concepts.

This concurs with the affirmation of Cohen, Brody and Sapon-Shevin (2004) that despite the welldocumented benefits of cooperative learning, and indeed a structured peer-mediation arrangement, implementing this pedagogical practice in classrooms is a challenge that many teachers seem to find difficult to accomplish.

Difficulties in implementation may occur where teachers do not have a clear understanding about how to establish effective cooperative groups, as indicated by one teacher in the following comments:

'What is this Cooperative Learning Method? Is it not where children work together in a group as we have always had it during our teaching? Does it have anything special? How should I answer some of the question items in this questionnaire? Okay, I will answer then you will tell me whether I have answered them correctly.'

Surprisingly every teacher indicated that they felt that they knew what CLM was. Others said that they employed it very often. Nevertheless, they did not appear to understand some question items with regards to the elements of CLM.

From the sessions observed, it would appear that everyday learning in many Kenyan schools to be mainly influenced by individualistic and competitive orientations. A possible reason for this could be the lack of opportunity for teachers to engage in professional development, either through constraints on time or because of a lack of adequate training to improve their delivery of mathematical concepts competences instruction. If this is the case, then this would need to be addressed not just at the level of individual schools, but also at county and maybe even national level.

\subsection{Teachers' Coordination Level, Traditional Methods and Learners' MCCA}

Teacher coordination of CLM activities entails both a considerable amount of preparation by teachers in order to have CLM work most effectively and also effective classroom management during facilitation of learning about mathematical concepts.

\subsubsection{Teacher Preparedness in Facilitating CLM and Learners' MCCA}

Observation of teacher preparedness in compiling professional records to facilitate CLM was carried out during the observed lesson and the data is presented in Table 4. 
Table 4: Teachers' Preparation Level and Learners' MCCA

Status

No of
teachers

Below Ap

Pre-school learners' MCCA

\begin{tabular}{rrrrrr} 
Expectation & $\begin{array}{c}\text { Approaching } \\
\text { Expectation }\end{array}$ & $\begin{array}{c}\text { Meeting } \\
\text { Expectation }\end{array}$ & $\begin{array}{c}\text { Exceeding } \\
\text { Expectation }\end{array}$ & $\begin{array}{c}\text { Status } \\
\%\end{array}$ \\
$\mathrm{~N}=20$ & $\mathrm{n}=7$ & $\mathrm{n}=61$ & $\mathrm{n}=190$ & $\mathrm{n}=381$ & $\mathrm{~N}=639$ \\
\hline
\end{tabular}

Teachers' Preparedness in Relation to Mean Score Index

\begin{tabular}{|c|c|c|c|c|c|c|}
\hline Low level & $45 \%$ & & $12 \%$ & $36 \%$ & & $46 \%$ \\
\hline Mid-level & $25 \%$ & & $9 \%$ & $28 \%$ & & $26 \%$ \\
\hline \multirow[t]{2}{*}{ High level } & $30 \%$ & & $6 \%$ & $22 \%$ & & $28 \%$ \\
\hline & $\mathrm{N}=20$ & $n=7$ & & $n=217$ & $\mathrm{n}=342$ & $=639$ \\
\hline
\end{tabular}

Provision of learning aids as planned in the scheme of work

\begin{tabular}{|c|c|c|c|c|c|c|}
\hline Done & $20 \%$ & $0 \%$ & $5 \%$ & $31 \%$ & $64 \%$ & $19 \%$ \\
\hline Not Done & $25 \%$ & $0 \%$ & $12 \%$ & $32 \%$ & $56 \%$ & $24 \%$ \\
\hline Not Applicable & $55 \%$ & $2 \%$ & $13 \%$ & $37 \%$ & $49 \%$ & $57 \%$ \\
\hline \multicolumn{7}{|c|}{ Provision of learning aids as planned in the lesson plan } \\
\hline Done & $25 \%$ & $0 \%$ & $5 \%$ & $21 \%$ & $73 \%$ & $24 \%$ \\
\hline Not Done & $25 \%$ & $0 \%$ & $13 \%$ & $34 \%$ & $53 \%$ & $24 \%$ \\
\hline Not Applicable & $50 \%$ & $2 \%$ & $14 \%$ & $40 \%$ & $44 \%$ & $52 \%$ \\
\hline
\end{tabular}

Table 4 illustrates that the level of teachers' preparation had a direct relationship with their learners' MCCA in that the higher the level of teachers' preparedness, the higher their learners' mathematical achievement. Although the majority of the learners were graded the highest (Exceeding Expectation) in all the three levels of teacher preparedness, the highest portion $(72 \%)$ of the learners were taught by teachers who had high level preparedness, $62 \%$ by teachers who had mid-level preparedness, while only $50 \%$ were taught by teachers with low level preparedness.

In the lower level grades, unsurprisingly, learners' achievement decreased as the grades lower, but the fewest learners in the lowest categories are those learners taught by teachers who had a high level of preparation. In other words, this means that the higher the teachers' level of preparedness, the fewer the learners who scored the lower grades (Below Expectation and Approaching Expectation). Through their preparation and professional development, teachers are able to develop their ability to use CLM to accomplish their lesson goals (Gillies, 2010).

Table 4 reveals that only a small portion of learners were taught by teachers who used learning resources as they had planned in their schemes of work and lesson plans (19\%) and 24\%) respectively. A slightly higher percentage of learners used learning resources, despite the fact that their teachers had not planned for them; either the scheme of work or the lesson plan, a figure of $24 \%$ of learners for both types of teaching document. The biggest percentages of learners were taught by teachers who had no schemes of work $(57 \%)$ and / or no lesson plans $(52 \%)$.

The highest achievers (those who Exceeded Expectation) were learners taught by teachers who had planned for their learning resources in the scheme of work and lesson plans (64\% and $73 \%$ respectively). Among those learners who Exceeded Expectation, the smallest percentage was for those learners who were taught by teachers who had neither scheme of work (49\%) nor lesson plans $(44 \%)$.

Nevertheless, it is important to note that more than half of the learners taught by teachers who provided them with learning aids, despite not having planned for these resources in the scheme of work $(56 \%)$ and lesson plans $(53 \%)$ were able to Exceed Expectation. It is also worth noting that there were a slightly higher percentage of teachers who used learning aids in their teaching who had planned for this in their lesson plan (24\%) more than those who had done their planning for the lesson in the scheme of work (19\%).

Furthermore, it must be borne in mind that without knowing the specific reasons why these teachers used resources that they did not plan for or chose not to use resources that they had planned for, it is very difficult to make a judgement about this based on a single lesson observation. Again, at national and at county level, the key element is to ensure that teachers receive adequate training in all aspects of their subject and teaching practice to ensure that they are able to deliver learning in a competent manner.

An analysis of schemes of work and lesson plans for a whole term was undertaken, where the data was informed by the previous term's archival records of schemes of work and lesson plans, in order to provide to the researcher with evidence of the trend in teachers' planning for CLM in their on-going weekly instruction of mathematical concepts. The rating was done by weighting the frequency of the teacher's preparation of both sets of documents for each of the 60 mathematical concept lessons for the previous term; frequencies of between 41 60 were weighted at high level preparation, 21 - 40 at mid-level preparation and 1 - 20 at low level preparation. This data is presented in Table 5. 
Table 5: Teacher's Preparedness and Learners' MCCA

\begin{tabular}{lrrrrr}
\hline \multirow{2}{*}{ Status } & $\begin{array}{c}\text { No of } \\
\text { teachers }\end{array}$ & $\begin{array}{c}\text { Below } \\
\text { Expectation }\end{array}$ & $\begin{array}{c}\text { Approaching } \\
\text { Expectation }\end{array}$ & $\begin{array}{c}\text { Meeting } \\
\text { Expectation }\end{array}$ & $\begin{array}{c}\text { Exceeding } \\
\text { Expectation }\end{array}$ \\
\cline { 2 - 6 } & $\mathrm{N}=20$ & $\mathrm{n}=7$ & $\mathrm{n}=73$ & $\mathrm{n}=217$ & $\mathrm{n}=342$ \\
\hline Scheme of work preparation in line with CLM & & & & \\
Low level preparation & $65 \%$ & $0 \%$ & $12 \%$ & $33 \%$ & $55 \%$ \\
Mid-level preparation & $5 \%$ & $0 \%$ & $11 \%$ & $36 \%$ & $50 \%$ \\
High level preparation & $30 \%$ & $2 \%$ & $34 \%$ & $53 \%$ \\
Low level preparation & & & Lesson plan of work preparation in line with CLM \\
Mid-level preparation & $20 \%$ & $1 \%$ & $6 \%$ & $32 \%$ & $54 \%$ \\
High level preparation & $0 \%$ & $1 \%$ & $0 \%$ & $42 \%$ & $51 \%$ \\
\hline
\end{tabular}

Table 5 shows that all the three categories of learners: with teachers with high level, mid-level and low level preparation had more than half of learners Exceeding Expectation (53\%, 50\% and 55\% consecutively). There appeared to be quite a small margin between category performances across the grades, despite the varied levels of preparation. This would indicate that there may be other contributory factors beyond teacher preparation that contribute to learners' MCCA and emphasises the fact that teachers need to carry out fully all the aspects of CLM in lessons in order to realise maximum benefits in their learners' development of competence in mathematical concepts.

In the sample studied, none of the learners were taught by teachers who had a high level of preparation for their lesson plans. On the other hand, learners taught by teachers with low-level preparation of both scheme of work and lesson plan had the highest level of achievement 55\% and 54\% at Exceeding Expectation compared with the low and mid-level preparation categories. This finding may have been realized as a result of some of the teachers who never indicated in their planning whether they used CLM teaching organization whereas they could have been using it (CLM organization) in their teaching.

The implication is that high level preparation by teachers appears to guarantee a higher level of achievement in competence in mathematical concepts by their learners. This is because successful implementation of CLM requires detailed planning and organisation by the teacher as the facilitator, making their role absolutely critical. In addition, lesson preparation needs to be done effectively and on a regular basis; therefore each teacher must know their learners well in order to plan appropriately for them (Gocer, 2010).

Table 5 highlights that from the teaching documents sampled, schemes of work appeared to have been done more consistently than lesson plans. In contrast to the lesson plans, it was notable that the schemes of work had verification signatures and stamps of the school head teacher which had been done early in the term. This process of needing to obtain stamps and signatures would have compelled the teachers to be more conscientious in preparing their schemes of work in order to present them to the school authority.

It may have not been a requirement for lesson plans to be signed and stamped and therefore, their absence. Lesson planning documentation in order to prepare for lessons that occur several times daily requires a significant amount of time and places a huge demand on the part of the teachers. In many cases, the lack of lesson plans may be due to the heavy workload shouldered by teachers by virtue of the large-sized classes in most Kenyan schools.

Of greater concern was the fact that a large number of those teachers who had no schemes of work or lesson plans did not even realise that they ought to have prepared them. They believed that it was already done for them by virtue of having the Competence Based Curriculum Design document. One teacher commented:

'The Competence Based Curriculum (CBC) document has every lesson's breakdown that one would need to do for the scheme of work. If anything, if a teacher would still be expected to prepare a scheme of work, there is no adequate training that pre-school teachers have been given on the same. Pre-school teachers are never included when lower primary school teachers are attending $C B C$ trainings facilitated by the local Curriculum Support Officers (CSOs) at the educational zone venues. We are told that pre-school teachers' training should be organised by the county government. Nonetheless, the content provided in the $C B C$ is even much cheaper than what we have always handled before.'

Another said:

'There is a new way of lesson planning as recommended and outlined in the CBC but it is quite complex and most of us have not been trained on the same. I just use the CBC design for the purposes of scheme of work and lesson plans and it works. My school administration has no issue with that fact, provided I as the teacher delivers.'

This would appear to demonstrate that some teachers are completely unaware of the requirement for them to adequately prepare and plan for their lessons through documentation. Consequently, through their lack of preparation and documentation, these teachers are less able to pay attention to the areas in which their learners 
may have deficits in mastering knowledge, and it is therefore difficult or almost impossible for them to know at what point they need to be putting remedial measures in place.

\subsection{Teachers' Provision of Learning Aids and Learners' MCCA}

The use of appropriate educational materials is as equally important as the use of effective teaching methods when presenting Mathematics lessons. Effective instruction depends on both the skill of the teacher and the quality of the resources that they use for teaching and learning (Gauther and Lawson, 2004). The study sought to assess the provision and use of learning aids in the facilitation of MCCA by teachers. The researcher observed the forms of learning aids used by the teachers in the delivery of mathematical concepts, their adequacy and whether they had been planned for in the professional documents for use in the learning process. The collected data is presented in Table 7.

Table 7: Teachers' Provision of Learning Resources and Learners' MCCA

\begin{tabular}{|c|c|c|c|c|c|c|}
\hline \multirow[t]{3}{*}{ Status } & \multirow{2}{*}{$\begin{array}{l}\text { No of } \\
\text { teachers }\end{array}$} & \multicolumn{5}{|c|}{ Pre-school learners' MCCA } \\
\hline & & $\begin{array}{c}\text { Below } \\
\text { Expectation }\end{array}$ & $\begin{array}{l}\text { Approaching } \\
\text { Expectation }\end{array}$ & $\begin{array}{c}\text { Meeting } \\
\text { Expectation }\end{array}$ & $\begin{array}{c}\text { Exceeding } \\
\text { Expectation }\end{array}$ & $\begin{array}{c}\text { Status } \\
\% \\
\end{array}$ \\
\hline & $\mathrm{N}=20$ & $\mathrm{n}=7$ & $\mathrm{n}=73$ & $\mathrm{n}=217$ & $\mathrm{n}=342$ & $\mathrm{~N}=639$ \\
\hline \multicolumn{7}{|c|}{ ailability of learning resources during the lesson } \\
\hline ne & $95 \%$ & $1 \%$ & $12 \%$ & $33 \%$ & $55 \%$ & $93 \%$ \\
\hline t Done & $5 \%$ & $2 \%$ & $7 \%$ & $52 \%$ & $39 \%$ & $7 \%$ \\
\hline \multicolumn{7}{|c|}{ equacy of the available learning resources } \\
\hline ne & $95 \%$ & $1 \%$ & $12 \%$ & $33 \%$ & $55 \%$ & $93 \%$ \\
\hline t Done & $5 \%$ & $2 \%$ & $7 \%$ & $52 \%$ & $39 \%$ & $7 \%$ \\
\hline
\end{tabular}

Table 7 shows that almost every learner (93\%) was provided with learning resources and only a small minority of them $(7 \%)$ were not. While more than half $(55 \%)$ of learners who were provided with learning resources Exceeded Expectation, more than half (52\%) of the learners who were not provided with learning resources were graded lower - at meeting Expectation. This appears to substantiate the notion that availability of learning resources influences utilisation of any hands-on method of learning (Muriithi, 2013), CLM being a good example.

With regard to the adequacy of resources, the study found that the available learning materials were adequate for almost all the learners (93\%). In the majority of cases, teachers shared most of the learning resources from the classroom learning corners. Making use of these resources was a guaranteed way of ensuring availability of learning materials whenever needed for learning in lessons. The need for adequate learning materials for particular class sizes is essential (Caven, 2009), which was demonstrated during the study, as classes on average varied in size between 20 and 30 learners. This is a favourable aspect to CLM given that a learner gets a chance to share personal experiences of others in addition to those of the individual learner.

From the researcher's observation, teachers employed a variety of learning aids, including some who employed more than one type of learning aid, as shown in Table 8. The types of learning materials provided in the classes observed included: sketches, bottle tops, letter cards, seeds, action songs, realia, and learners themselves were used as counters.

Table 8: Forms of Learning Resources Applied in the Lesson and Learners' MCCA

\begin{tabular}{|c|c|c|c|c|c|c|}
\hline \multirow[t]{3}{*}{ Status } & \multirow{2}{*}{$\begin{array}{c}\text { No of } \\
\text { teachers }\end{array}$} & \multicolumn{5}{|c|}{ Pre-school learners' MCCA } \\
\hline & & $\begin{array}{c}\text { Below } \\
\text { Expectation }\end{array}$ & \multirow{2}{*}{$\begin{array}{r}\begin{array}{l}\text { Approaching } \\
\text { Expectation }\end{array} \\
\qquad n=73\end{array}$} & \multirow{2}{*}{$\begin{array}{r}\begin{array}{c}\text { Meeting } \\
\text { Expectation }\end{array} \\
\mathrm{n}=217 \\
\end{array}$} & \multirow{2}{*}{$\begin{array}{r}\begin{array}{l}\text { Exceeding } \\
\text { Expectation }\end{array} \\
\mathrm{n}=342 \\
\end{array}$} & \multirow{2}{*}{$\begin{array}{c}\begin{array}{c}\text { Status } \\
\%\end{array} \\
\mathrm{~N}=639 \\
\end{array}$} \\
\hline & $\mathrm{N}=20$ & $\mathrm{n}=7$ & & & & \\
\hline \multicolumn{7}{|c|}{ Visual learning aids applied } \\
\hline Done & $60 \%$ & $2 \%$ & $17 \%$ & $40 \%$ & $42 \%$ & $55 \%$ \\
\hline Not Done & $40 \%$ & $1 \%$ & $5 \%$ & $27 \%$ & $68 \%$ & $45 \%$ \\
\hline \multicolumn{7}{|c|}{ Audio learning aids applied } \\
\hline Done & $0 \%$ & $0 \%$ & $0 \%$ & $0 \%$ & $0 \%$ & $0 \%$ \\
\hline Not Done & $100 \%$ & $1 \%$ & $11 \%$ & $34 \%$ & $54 \%$ & $100 \%$ \\
\hline \multicolumn{7}{|c|}{ Audio visual learning aids applied } \\
\hline Done & $0 \%$ & $0 \%$ & $0 \%$ & $0 \%$ & $0 \%$ & $0 \%$ \\
\hline Not Done & $100 \%$ & $1 \%$ & $11 \%$ & $34 \%$ & $54 \%$ & $100 \%$ \\
\hline \multicolumn{7}{|c|}{ Tactile learning aids applied } \\
\hline Done & $65 \%$ & $0 \%$ & $8 \%$ & $27 \%$ & $65 \%$ & $65 \%$ \\
\hline Not Done & $35 \%$ & $3 \%$ & $18 \%$ & $47 \%$ & $32 \%$ & $35 \%$ \\
\hline
\end{tabular}

From Table 8 it is evident that more than half $(55 \%)$ of the learners were provided with visual learning aids, while almost two thirds $(65 \%)$ were provided with tactile learning aids. No audio or audio-visual learning aids 
were provided. The data in Table 8 shows that tactile learning aids are favoured over audio ones for learner achievement. For optimal results, use of these materials should not be limited to teacher demonstration, but rather learners must be given the opportunity to make use of them in meaningful ways.

Less than half (42\%) of learners who had access to visual resources Exceeded Expectation, whereas $68 \%$ learners who used another type of learning resource (specifically tactile resources) Exceeded Expectation. The majority of learners (65\%) who used tactile learning resources Exceeded Expectation, whereas only 32\% of those who used an alternative (visual learning aids) Exceeded Expectation.

Table 9 shows the documentary analysis regarding frequency of learning materials provided.

Table 9: Documentary Analysis of Learning Material Provision and Learners' MCCA

Status

$$
\text { No of }
$$

teachers

\begin{tabular}{crrrrr}
\multicolumn{6}{c}{ Pre-school learners' MCCA } \\
\cline { 2 - 6 } & $\begin{array}{c}\text { Below } \\
\text { Expectation }\end{array}$ & $\begin{array}{c}\text { Approaching } \\
\text { Expectation }\end{array}$ & $\begin{array}{c}\text { Meeting } \\
\text { Expectation }\end{array}$ & $\begin{array}{c}\text { Exceeding } \\
\text { Expectation }\end{array}$ & $\begin{array}{c}\text { Status } \\
\%\end{array}$ \\
\hline & $\mathrm{n}=7$ & $\mathrm{n}=73$ & $\mathrm{n}=217$ & $\mathrm{n}=342$ & $\mathrm{~N}=639$ \\
\hline
\end{tabular}

Teacher frequency of provision of learning materials to the learning groups

\begin{tabular}{|c|c|c|c|c|c|c|}
\hline Never/not indicated & $60 \%$ & $2 \%$ & $12 \%$ & $47 \%$ & $42 \%$ & $33 \%$ \\
\hline Rarely & $0 \%$ & $0 \%$ & $0 \%$ & $0 \%$ & $0 \%$ & $0 \%$ \\
\hline Often & $0 \%$ & $0 \%$ & $0 \%$ & $0 \%$ & $0 \%$ & $0 \%$ \\
\hline Very Often & $40 \%$ & $1 \%$ & $11 \%$ & $26 \%$ & $64 \%$ & $67 \%$ \\
\hline
\end{tabular}

Table 9 indicates that the majority of learners (67\%) were provided with learning materials very often and the majority of them (64\%) Exceeded Expectation. However, it was striking to note that for $60 \%$ of learners there was no evidence of their teachers ever providing them with learning materials; however, this may have been due to their teachers not indicating that they provide materials even though they actually do so. This saw the highest achieved grade to be meeting Expectation (47\%). None of the teachers were noted as either rarely providing or often providing learning resources to their learners. This is probably because most of them sourced the learning resources from their classes' learning corners, where they were readily available.

It is worth noting that Njoroge and Githua (2013) found when they were researching the causes of poor performance in Murang'a County that lack of available learning materials was a major factor that hampered learners' understanding of mathematical concepts.

The teachers' opinion about the extent of their provision of learning materials for their learners was elicited by the use of a questionnaire, as presented in Table 10 .

Table 10: Teachers' Provision of Learning Aids to Learners and Learners' MCCA

\begin{tabular}{|c|c|c|c|c|c|c|}
\hline \multirow[t]{3}{*}{ Status } & \multirow{2}{*}{$\begin{array}{c}\text { No of } \\
\text { teachers }\end{array}$} & \multicolumn{5}{|c|}{ Pre-school learners' MCCA } \\
\hline & & $\begin{array}{c}\text { Below } \\
\text { Expectation }\end{array}$ & $\begin{array}{l}\text { Approaching } \\
\text { Expectation }\end{array}$ & $\begin{array}{c}\text { Meeting } \\
\text { Expectation }\end{array}$ & $\begin{array}{l}\text { Exceeding } \\
\text { Expectation }\end{array}$ & $\begin{array}{c}\text { Status } \\
\%\end{array}$ \\
\hline & $\mathrm{N}=20$ & $\mathrm{n}=7$ & $\mathrm{n}=73$ & $\mathrm{n}=217$ & $\mathrm{n}=342$ & $\mathrm{~N}=639$ \\
\hline \multicolumn{7}{|c|}{ Teachers' providing learning materials } \\
\hline Never/not indicated & $55 \%$ & $0 \%$ & $0 \%$ & $0 \%$ & $0 \%$ & $0 \%$ \\
\hline Rarely & $40 \%$ & $0 \%$ & $0 \%$ & $0 \%$ & $0 \%$ & $0 \%$ \\
\hline Often & $5 \%$ & $0 \%$ & $15 \%$ & $34 \%$ & $51 \%$ & $6 \%$ \\
\hline Very Often & $0 \%$ & $1 \%$ & $11 \%$ & $32 \%$ & $50 \%$ & $94 \%$ \\
\hline
\end{tabular}

Table 10 indicates that the vast majority of learners $(94 \%)$ were said to be provided very often with adequate learning materials. Teacher opinion was almost the same as that about the extent of the provision of learning materials. This appears to indicate the difference between the ideal and the reality: teachers understand the necessity for learning aids in the learning process; however, it is not always possible to provide them, which may be due to unavailability or inadequacy of materials, as well as teacher failure to make use of resources. Using learning aids, particularly tactile ones, is beneficial because this gives learners the opportunity to manipulate them, thereby developing finger muscle dexterity and fine psychomotor skills. Furthermore, these aids foster observational skills, as well as raising learning interest in learners (Mohammad, 2004).

\section{4: Time Taken in CLM Activities and Learners' MCCA}

Table 11 presents the data collected using the observation schedule during the learning session of the actual observation of teachers' time taken in CLM activities. 
Table 11: Observed Teachers' Time Taken in CLM Activities and Learners' MCCA

\begin{tabular}{|c|c|c|c|c|c|c|}
\hline \multirow[t]{3}{*}{ Status } & \multirow{2}{*}{$\begin{array}{c}\text { No of } \\
\text { teachers }\end{array}$} & \multicolumn{5}{|c|}{ Pre-school learners' MCCA } \\
\hline & & $\begin{array}{c}\text { Below } \\
\text { Expectation }\end{array}$ & $\begin{array}{l}\text { Approaching } \\
\text { Expectation }\end{array}$ & $\begin{array}{c}\text { Meeting } \\
\text { Expectation }\end{array}$ & $\begin{array}{l}\text { Exceeding } \\
\text { Expectation }\end{array}$ & $\begin{array}{c}\text { Status } \\
\%\end{array}$ \\
\hline & $\mathrm{N}=20$ & $\mathrm{n}=7$ & $\mathrm{n}=73$ & $\mathrm{n}=217$ & $\mathrm{n}=342$ & $\mathrm{~N}=639$ \\
\hline \multicolumn{7}{|c|}{ cher setting rules to be followed the CLM groups } \\
\hline & $15 \%$ & $2 \%$ & $11 \%$ & $34 \%$ & $54 \%$ & $89 \%$ \\
\hline Done & $85 \%$ & $0 \%$ & $16 \%$ & $38 \%$ & $46 \%$ & $11 \%$ \\
\hline \multicolumn{7}{|c|}{ cher designing tasks to be undertaken by each CLM group } \\
\hline & $25 \%$ & $1 \%$ & $11 \%$ & $34 \%$ & $54 \%$ & $100 \%$ \\
\hline Done & $75 \%$ & $0 \%$ & $0 \%$ & $0 \%$ & $0 \%$ & $0 \%$ \\
\hline \multicolumn{7}{|c|}{ acher observing learners' individual work by random checking } \\
\hline & $0 \%$ & $1 \%$ & $11 \%$ & $34 \%$ & $54 \%$ & $18 \%$ \\
\hline Done & $100 \%$ & $1 \%$ & $12 \%$ & $34 \%$ & $53 \%$ & $82 \%$ \\
\hline \multicolumn{7}{|c|}{ acher observing learners' individual work by asking them to explain their answers } \\
\hline & $20 \%$ & $1 \%$ & $7 \%$ & $35 \%$ & $57 \%$ & $51 \%$ \\
\hline Done & $80 \%$ & $2 \%$ & $16 \%$ & $36 \%$ & $47 \%$ & $49 \%$ \\
\hline \multicolumn{7}{|c|}{ acher observing learners' individual work by assigning them various roles } \\
\hline & $0 \%$ & $2 \%$ & $12 \%$ & $32 \%$ & $54 \%$ & $57 \%$ \\
\hline Done & $100 \%$ & $0 \%$ & $10 \%$ & $37 \%$ & $52 \%$ & $43 \%$ \\
\hline \multicolumn{7}{|c|}{ cher specifying time for CLM groups' task completion } \\
\hline ne & $0 \%$ & $0 \%$ & $9 \%$ & $18 \%$ & $73 \%$ & $37 \%$ \\
\hline done & $100 \%$ & $2 \%$ & $14 \%$ & $45 \%$ & $40 \%$ & $63 \%$ \\
\hline
\end{tabular}

Table 11 highlights the impact of the variation in teacher activities, but with a similar trend: the lower the grade, the lower the percentage was of learners who achieved, whereas the higher the grade, the higher the number of learner achievers rose. There is a consistency in the achievement of learners whose teachers undertook CLM activities and those who scored the highest grade (Exceeding Expectation) in greater numbers compared to their peers, whose teachers never took time in undertaking CLM activities.

Organising learning in small groups does not necessarily imply that students will work together and support each other in mastering their learning tasks. Occasionally, in the highest category (Exceeding Expectation), there were learners who were taught by teachers who took time in undertaking CLM activities but who did not achieve $50 \%$. These were in situations where teachers did not undertake the CLM requirements of setting rules to be followed by the CLM groups (46\%), observing learners' individual work by asking them to explain their answers (47\%) or specifying time for the completion of the CLM group tasks (40\%). If these activities are not undertaken successfully, cooperative learning is less likely to be very effective.

Every teacher $(100 \%)$ designed learning tasks to be undertaken by each one of their CLM groups. There was no unduly significant disparity in the achievement of competence in mathematical concepts in many of the CLM activities undertaken by teachers, except where teachers specified time for the completion of a CLM group task. There was a relatively large disparity between the $73 \%$ of learners whose teachers specified time for their CLM group tasks completion and the $40 \%$ of those whose teachers did not do this.

In every grade category, the achievement of learners whose teachers took time to undertake CLM activities was always above the average mean score for each grade (54\%). Teachers who set rules to be followed in the CLM groups, who specified time for the completion of CLM group tasks, who designed tasks for each CLM group, and who observed individuals' work by random checking, asking them to explain their answers and by assigning them various roles achieved $54 \%, 54 \%, 73 \%, 57 \%, 54 \%$ and $54 \%$ consecutively.

Notably, although teachers never used all of the measures specified by CLM when undertaking the lesson, they used at least one or two of them alternately. Other observations made indicated that:

When setting rules, some classes only received general instructions from the teacher, where both learning groups and whole class group organisation was applied.

When designing of tasks to be undertaken by learners, some teachers gave direction to the groups by prompting them on what to do.

When teachers observed learners' individual work, some individual learners were appointed to act on the teacher's prompts as other learners were following. In other cases, some teachers just went round marking the learners' individual work around the class. If anything, in some cases, learners were working individually and not in a group setting. In some other cases, learning groups were rotated to assess completed learning work/tasks by other groups. Most often, specifying time for CLM group task completion was done at the end of the task where the teacher called the class to order when the lesson came to an end.

Implementing learning in small groups needs careful consideration. Not only must learning tasks be carefully 
structured, but consideration must also be given to how the teacher takes time to set conditions and processes that enhance social interaction between team mates.

A documentary analysis of the time taken by teachers in carrying out CLM activities was undertaken, as presented in Table 12.

Table 12: Documented Teachers' Time Taken in CLM Activities and Learners' MCCA

\section{Status}

No of
teachers

Exp

Below Pre-school learners' MCCA

\begin{tabular}{rrrrr}
$\begin{array}{c}\text { Below } \\
\text { Expectation }\end{array}$ & $\begin{array}{c}\text { Approaching } \\
\text { Expectation }\end{array}$ & $\begin{array}{c}\text { Meeting } \\
\text { Expectation }\end{array}$ & $\begin{array}{c}\text { Exceeding } \\
\text { Expectation }\end{array}$ & $\begin{array}{c}\text { Status } \\
\%\end{array}$ \\
$\mathrm{n}=7$ & $\mathrm{n}=73$ & $\mathrm{n}=217$ & $\mathrm{n}=342$ & $\mathrm{~N}=639$ \\
\hline
\end{tabular}

Frequency of setting rules to be followed by learning groups

\begin{tabular}{|c|c|c|c|c|c|c|}
\hline Never/ not indicated & $60 \%$ & $1 \%$ & $10 \%$ & $26 \%$ & $64 \%$ & $57 \%$ \\
\hline Rarely & $0 \%$ & $2 \%$ & $13 \%$ & $45 \%$ & $40 \%$ & $43 \%$ \\
\hline Often & $0 \%$ & $0 \%$ & $0 \%$ & $0 \%$ & $0 \%$ & $0 \%$ \\
\hline Very often & $40 \%$ & $0 \%$ & $0 \%$ & $0 \%$ & $0 \%$ & $0 \%$ \\
\hline \multicolumn{7}{|c|}{ Frequency of designing tasks for learning groups } \\
\hline Never/ not indicated & $100 \%$ & $1 \%$ & $11 \%$ & $27 \%$ & $62 \%$ & $56 \%$ \\
\hline Often & $0 \%$ & $0 \%$ & $0 \%$ & $0 \%$ & $0 \%$ & $0 \%$ \\
\hline Very often & $0 \%$ & $0 \%$ & $0 \%$ & $0 \%$ & $0 \%$ & $0 \%$ \\
\hline Very often & $0 \%$ & $2 \%$ & $12 \%$ & $42 \%$ & $43 \%$ & $44 \%$ \\
\hline \multicolumn{7}{|c|}{ Frequency of specifying time for completion of tasks by learning groups } \\
\hline Never/ not indicated & $65 \%$ & $0 \%$ & $11 \%$ & $29 \%$ & $60 \%$ & $60 \%$ \\
\hline Rarely & $0 \%$ & $2 \%$ & $12 \%$ & $42 \%$ & $44 \%$ & $40 \%$ \\
\hline Often & $0 \%$ & $0 \%$ & $0 \%$ & $0 \%$ & $0 \%$ & $0 \%$ \\
\hline Very often & $35 \%$ & $0 \%$ & $0 \%$ & $0 \%$ & $0 \%$ & $0 \%$ \\
\hline
\end{tabular}

Table 12 presents data collected using the documentary analysis guide. None of the learners were taught by teachers who rarely or often set rules to be followed by learning groups and none of them were taught by teachers who rarely or often took time specifying the time limit for the completion of tasks. The majority of the teachers either never undertook the setting of rules to be followed $(57 \%)$, designing tasks (56\%) or specifying time for completion of tasks $(60 \%)$ or did not indicate it in the documents seen and analysed.

Interestingly, the majority of learners taught by teachers who either never took time undertaking CLM activities or where it was not indicated Exceeded Expectation at $60 \%, 62 \%$ and $64 \%$ consecutively. It is therefore possible that the details indicating the implementation of CLM activities were never included in the documentation. This would most likely be due to the fact that most of the lesson plans made available to the researcher were extremely brief and the reality is that establishing cooperative learning in a classroom requires teacher commitment to embedding the procedures into the pre-school curriculum and in implementing, monitoring, and evaluating it (Gillies \& Boyle, 2010).

Teacher opinion on their frequency of carrying out various CLM activities, collected through the questionnaire, is presented in Table 13.

Table 13: Teachers' Opinion on Time Taken in CLM Activities and Learners' MCCA

\begin{tabular}{|c|c|c|c|c|c|c|}
\hline \multirow[t]{3}{*}{ Status } & \multirow{2}{*}{$\begin{array}{c}\text { No of } \\
\text { teachers }\end{array}$} & \multicolumn{5}{|c|}{ Pre-school learners' MCCA } \\
\hline & & $\begin{array}{c}\text { Below } \\
\text { Expectation }\end{array}$ & $\begin{array}{l}\text { Approaching } \\
\text { Expectation }\end{array}$ & $\begin{array}{c}\text { Meeting } \\
\text { Expectation }\end{array}$ & $\begin{array}{c}\text { Exceeding } \\
\text { Expectation }\end{array}$ & $\begin{array}{c}\text { Status } \\
\% \\
\end{array}$ \\
\hline & $\mathrm{N}=20$ & $\mathrm{n}=7$ & $\mathrm{n}=73$ & $\mathrm{n}=217$ & $\mathrm{n}=342$ & $\mathrm{~N}=639$ \\
\hline \multicolumn{7}{|l|}{ Teachers' setting rules } \\
\hline Never or not indicated & $35 \%$ & $0 \%$ & $0 \%$ & $0 \%$ & $0 \%$ & $0 \%$ \\
\hline Rarely & $60 \%$ & $0 \%$ & $0 \%$ & $0 \%$ & $0 \%$ & $0 \%$ \\
\hline Often & $0 \%$ & $0 \%$ & $0 \%$ & $11 \%$ & $89 \%$ & $7 \%$ \\
\hline Very Often & $5 \%$ & $1 \%$ & $11 \%$ & $36 \%$ & $51 \%$ & $93 \%$ \\
\hline \multicolumn{7}{|c|}{ Teachers' designing tasks } \\
\hline Never or not indicated & $55 \%$ & $0 \%$ & $0 \%$ & $0 \%$ & $0 \%$ & $0 \%$ \\
\hline Rarely & $40 \%$ & $0 \%$ & $0 \%$ & $0 \%$ & $0 \%$ & $0 \%$ \\
\hline Often & $5 \%$ & $0 \%$ & $15 \%$ & $34 \%$ & $51 \%$ & $6 \%$ \\
\hline Very Often & $0 \%$ & $1 \%$ & $14 \%$ & $40 \%$ & $63 \%$ & $94 \%$ \\
\hline \multicolumn{7}{|c|}{ Teachers' specifying time for the task completion } \\
\hline Never or not indicated & $45 \%$ & $0 \%$ & $0 \%$ & $0 \%$ & $0 \%$ & $0 \%$ \\
\hline Rarely & $50 \%$ & $0 \%$ & $0 \%$ & $0 \%$ & $0 \%$ & $0 \%$ \\
\hline Often & $5 \%$ & $0 \%$ & $0 \%$ & $3 \%$ & $97 \%$ & $5 \%$ \\
\hline Very Often & $0 \%$ & $1 \%$ & $14 \%$ & $42 \%$ & $62 \%$ & $96 \%$ \\
\hline
\end{tabular}


Table 13 shows teachers' responses on their perceived level of time taken in CLM activities (as per the questionnaire completed by teachers) that reflected a variation from what was observed in the learning session. Although the majority of teachers did not apply all three of the CLM coordination activities, none indicated that they never did it. Almost every teacher indicated that they set rules $(93 \%)$, designed tasks (94\%) and specified time for task completion (96\%). Where teachers set rules, almost every learner Exceeded Expectation (89\%), compared with teachers who indicated that they did it very often, who only had about half (51\%) of their learners Exceeding Expectation.

Even though the majority of learners taught by teachers who designed learning tasks Met and Exceeded Expectation, a larger percentage of learners Below Expectation or Approaching Expectation had teachers who said that they did it very often. There were no learners below Expectation or Approaching Expectation among learners taught by teachers who specified time for task completion often, compared to those who said that they did it very often.

Teachers' reluctance to embrace CLM may also be due to the lack of time to learn about peer-mediated approaches, because of the challenge they perceive it might pose to their control of the learning process, the demands it places on classroom organisational changes, or the professional commitments required to sustain their efforts (Cohen et al., 2004). This perception may cause teachers to prefer traditional teaching methods over CLM, where they learners spend more time listening to what the instructor has to say (Kamau, 2010). This diminishes learners' chances of benefiting from the concept of CLM as an instructional method in which they work together with the aim of maximising their own and each other's learning in the pursuit of a common objective.

\subsection{Teacher Interaction Level in CLM Facilitation and Learners' MCCA}

There is a great need for social interaction between group members, as well as support at individual level, to avoid adverse experiences when learners face challenges in their learning teams, such as controversial suggestions, ideas and strategies. Teachers can support by maintaining discipline, assessing completed tasks, providing feedback on performance and monitoring learner contributions.

\subsection{Regression Model on Teacher Facilitation of CLM and Learners' MCCA}

To determine the contribution made by the teacher's facilitation of CLM to MCCA, the data was subjected to a regression model procedure. This is presented in Table 14.

Table 14: Regression Model on Teacher Facilitation of CLM and Learners' MCCA

\begin{tabular}{|c|c|c|c|c|c|c|}
\hline Model & $\begin{array}{l}\mathrm{R} \\
0.392^{\mathrm{a}}\end{array}$ & $\begin{array}{l}\text { R Square } \\
0.154\end{array}$ & $\begin{array}{l}\text { Adjusted R Squa } \\
0.461\end{array}$ & $\begin{array}{l}\text { Std. Erro } \\
0.676\end{array}$ & of the Estir & \\
\hline ANOV & on Teachers' CLM Facilita & on and Le & Irners' MCCA & & & \\
\hline Model & Sum & Squares & df & Mean Square & $\mathrm{F}$ & Sig. \\
\hline & Regression & 52.457 & 5 & 8.743 & 19.134 & $.000^{\mathrm{b}}$ \\
\hline & Residual & 288.782 & 633 & 0.457 & & \\
\hline & Total & 341.239 & 638 & & & \\
\hline Coeffic & nts of Teachers' CLM Faci & tation and & earners' MCCA & & & \\
\hline Model & & $\begin{array}{l}\text { Unstandar } \\
\text { Coefficien }\end{array}$ & lised & $\begin{array}{l}\text { Standardised } \\
\text { Coefficients }\end{array}$ & $\mathrm{t}$ & Sig. \\
\hline & & B & Std. Error & Beta & & \\
\hline & (Constant) & 3.221 & 0.194 & & 16.626 & 0.000 \\
\hline & Availability of Groupings & 0.472 & 0.057 & 0.323 & 8.240 & 0.000 \\
\hline & Teacher preparedness & 0.092 & 0.060 & 0.106 & 1.538 & 0.125 \\
\hline & $\begin{array}{l}\text { Level of Provision of } \\
\text { Learning Resources }\end{array}$ & 0.173 & 0.069 & 0.130 & 2.486 & 0.013 \\
\hline & $\begin{array}{l}\text { Time taken in CLM } \\
\text { Activities }\end{array}$ & 0.207 & 0.046 & 0.217 & 4.533 & 0.000 \\
\hline & Level of Interaction & 0.149 & 0.039 & 0.186 & 3.769 & 0.000 \\
\hline
\end{tabular}

a. a. Dependent Variable: Mathematical Concepts Competences Acquisition

b. b. Predictors: (Constant), Availability of Groupings and Teacher preparedness, Level of Provision of Learning Resources, Level of Coordination, Level of Interaction, Time taken in CLM Activities

Table 14 shows Regression analysis of the relationship between the identified predictor variables: availability of groupings and teacher preparedness, level of provision of learning resources, level of coordination, level of interaction, time taken in CLM activities and the dependent variable (mathematical concepts competences acquisition (MCCA). The analysis showed that $\mathrm{R}=0.392$, $\mathrm{R}$ Square $=0.154$ and adjusted $\mathrm{R}$ Square $=0.461$ with a standard error of the estimate at 0.676. This means that for pre-school learners in Kirinyaga County, $46.1 \%(0.461 \times 100)$ of the MCCAT achievement would be attributed to the use of CLM as an 
instructional method. This confirms the finding by Gubbad (2010) that CLM changes classroom learning dynamics where groups of learners, even at pre-school level, share classroom learning facilitation collectively. As a result, it is no longer the exclusive duty of the instructor to impart mathematical concepts to the learners but they too actively construct their own knowledge, hence improving their learning performance.

ANOVA also produced the statistics $(\mathrm{F}(5,633=19.134, \mathrm{p}<0.05, \mathrm{p}<0.000)$ and the coefficients are: $\beta=0.323$, $0.106,0.150,0.130,0.217$ and $0.186 ; \mathrm{t}=8.240,1.538,2.172 .2 .486,4.533$ and 3.769 ; and $\mathrm{p}=0.000,0.125,0.030$, $0.013,0.000$ and 0.000 consecutively.

The findings indicate that the regression model is a significant predictor of MCCA. It therefore means that teacher facilitation of mathematical concepts competences using CLM is a significant predictor of MCCA in Kirinyaga County. However, teacher preparedness, as a variable in teacher facilitation of CLM, was found to be an insignificant predictor of MCCA in pre-school learners in Kirinyaga County. This finding seems to partially agree with research studies by Edwards et al., (2000) and Ukpokodu (2002) where it was difficult to identify specific mode of preparedness related to teacher effectiveness.

The Correlation coefficients show that a unit increase in the availability of groupings, level of provision of learning resources, level of coordination, level of interaction and time taken in CLM activities would increase the MCCA of pre-school learners in Kirinyaga County by 1.112 units $(0.323+0.106+0.150+0.130+0.217+$ 0.186). This is because CLM positively correlates with mathematical concepts acquisition of the learners in Kirinyaga County.

\subsection{Conclusion and Recommendation}

It is imperative to note that CLM offers a learner-centred experience where learners develop their psychomotor skills as they manipulate learning resources during their activities. These physical activities are scaffolded to stimulate intellectual development as they utilise the learning resources, activities which include solving mathematical concepts competences problems, as well as discoveries of new ideas. Teachers' facilitation of CLM enables learners to make the best use of the given opportunities for enquiry and discovery learning. This cultivates a great deal of interest in learners that becomes a springboard for their involvement in the learning tasks, skills and the subject matter. The study recommends that the Ministry of Education should develop programmes and policies that provide regular in-service training, in which CLM training forms a key part of the agenda and to refresh the mathematical concepts competences instructional skills of pre-school teachers.

\section{References}

Adams, R. (2013). Cooperative Learning Effects on the Classroom. Master's Thesis, Northern Michigan University

Adebayo, S. (2014). Comparative Study of Effectiveness of Cooperative Learning Strategy and Traditional Instructional Method in the Physics Classroom. European Journal of Educational Sciences, 1(1), 30-41

Alshammari, M. (2015). Effects of Cooperative Learning Method on Competences Performance of College Learners in Saudi Arabia. Masters' Thesis, University of New York.

Angadi, G. \& Darga, A. (2015). Effect of Cooperative Learning on Academic Achievement of Ix-Standard Learners in Mathematics. International Journal of Teacher Educational Research, 4(2), 1-8

Anobile, G., Cicchini, G. M. \& Burr, D. C. (2012). Linear Mapping of Numbers Onto Space Requires Attention. Cognition 122, 454-459

Caven, S. M (2009). Positive Peer Group Interventions: An Alternative to Individual Interventions For Promoting Prosocial Behaviour in Potentially Disaffected Youth. Electronic Journal of Research in Education Psychology , 7(3), 1131 - 1156. 2009

Chen, Q. \& Li, J. (2014). Association between Individual Differences in Non-Symbolic Number Acuity and Mathematical Activities Performance: A Meta-Analysis. Acta Psychol. (Amst). 148, 163-172.

Clindiebere, M. (2013). The Impact of Cooperative Instructional Strategy on the Performance of Grade 09 Learners in Science. Pretoria: University of South Africa.

Cohen, E. G., Brody, C. M., \& Sapon-Shevin, M. (2004). Teaching Cooperative Learning. The Challenge for Teacher Education. New York: State University of New York.

Cohen, E. G., Brody, C. M., \& Sapon-Shevin, M. (2004). Teaching Cooperative Learning. The Challenge for Teacher Education. New York: State University of New York.

Cohen, E. G., Brody, C. M., \& Sapon-Shevin, M. (2004). Teaching Cooperative Learning. The Challenge for Teacher Education. New York: State University of New York.

Edwards, S., McNamara, K., \& Carter, K. (2000). Teacher education: Preparing teachers for diversity. Paper presented at the Annual Meeting of the American Educational Research Association, New Orleans, LA

Felder, R. M. \& Brent, R. (2012). Cooperative learning method. Washington, DC: American Chemical Society, pp.34-53.

Fraser, B. J. \& Kahle, J. B. (2014). Classroom, Home and Peer Environment Influences on Student Outcomes in 
Science and Mathematical Activities: An Analysis of Systemic Reform Data, International Journal of Science Education, 29(15): 1891-1909. Accessed at: http://www.journal.naeyc.org/btj/200401/Raver.pdf

Gillies, R. M., \& Boyle, M. (2010). Teacher's Reflections on Cooperative Learning Method: Issues of Implementation. Teaching and Teacher Education, 26(4), 933-940.

Gocer, A. (2010). A comparative research on the effectivity of cooperative learning method and jigsaw technique on teaching literary genres. Educational Research and Reviews, 5(8), 439-445.

Gubbad, A. (2010). Effect of Cooperative Learning Method on the Competences Achievement and Retention of the Mathematical Activities' Concepts at the Primary School in Holy Makkah. Education, Science and Islamic Studies, 22(2): 13-23.

Huber, S. G and Skedsmo (2016). Assessment in Education - FromEarly Childhood to Higher Education. Springer Science Business Media. New York.

Johnson, D. W., \& Johnson, R. T. (2009). An Educational Psychology Success Story: Social Interdependence Theory and Cooperative Learning. Educational Researcher, 38(5), 365-379. doi: 10.3102/0013189X09339057: http://dx.doi.org/10.3102/0013189X09339057: Retrieved from Sage

Johnson, D., \& Johnson, R. (2014). Cooperative Learning Method and Achievement. New York: Praeger.

Kalawole, B. (2007). Effects of Competitive and Cooperative Learning Strategies on Academic Performance of Nigerian Learners in Mathematics. Educational Research and Review, 3 (1), 3337.

Kamau, P. (2015). Effects of Cooperative Learning Method Approach on Competences Achievement of Secondary School Learners in Mathematical Activities in Kangema District, Murang'a County, Kenya. Master's Thesis, Kenyatta University.

Kognitionen in der Pädagogischen Praxis [Action-guiding cognitions in educational

Lou, Y., Abrami, P., Spence, J., Poulsen, C., Chambers, B., \& d'Apollonia, S. (2013). Within-Class Grouping: A Meta-Analysis. Review of Educational Research, 66, 423-458.

McLoughlin, Caven S. (2009). Positive Peer Group Interventions: An Alternative to Individualized Interventions for Promoting Prosocial Behavior in Potentially Disaffected. Youth Electronic Journal of Research in Educational Psychology, vol. 7, núm. 3, diciembre, pp. 1131-1156

Mentz, E., Van der Walt, J. L. \& Goosen, L. (2010). The effect of incorporating cooperative learning method principles in pair programming for student teachers. Computer Science Education, 18(4): pp.247-260.

Mohammad, M. (2004).The Impact of Cooperative Learning in Teaching Mathematics. Problems. Resources and Issues in Mathematics Under graduate Studies, 16(3), 2000-225

Muriithi, E. M. (2013). Impact of Project Method on Learner's Competences Achievement in Physics in Provincial Public Secondary Schools in Kenya. PhD Thesis, University of Nairobi

Ngusa, J., Begi, N. \& Ndani, M. (2018). Relationship between School Learning Environment and Pupils' Performance in Mathematical Activities in Kirinyaga County, Kenya, European Journal of Education Studies, 4(5): 12-44.

Njoroge, J. \& Githua, B. (2013). Effect of Cooperative Learning Method/Teaching Strategy on Learner's Mathematical Activities 'Achievement by Gender. Asian Journal of Social Sciences and Humanities, 2(2): 567-577.

Ojedapo, D., Fazio, L. K., Bailey, D. H., Thompson, C. A. \& Siegler, R. S. (2014). Relations of Different Types of Numerical Magnitude Representations to Each Other and to Mathematical Activities Achievement. J. Exp. Child Psychol. 123, 53-72.

on Social Learning in Schools]. In C. Dalbert \& E. J. Brunner, (Eds.): Handlungsleitende

Parr, B. A. (2003). Improving Student Achievement in Mathematics: An Important Role For practice] (p. 119137). Baltmannsweiler: Schneider-Verlag Hohengehren

Rotering-Steinberg, S. (2000): Untersuchungen Zum Sozialen Lernen in Schulen [Studies

Rudhumbu, N. (2014). The Use of Motivational Teaching Method in Primary School Mathematical Activities in Zimbabwe: A Case of the First Decade after Independence. British Journal of Education, 2(3): 22-36.

Secondary Agricultural Education in the 21st Century. Unpublished Manuscript. College

Shinn, G. C., Briers, G. E., Christiansen, J. E., Edwards, M. C., Harlin, J. F., Lawver, D. E., .

Singh, K., Granville, M. \& Dika, S. (2012). Mathematical Activities and Science Achievement: Effects of Motivation, Interest, and Competences Engagement. Journal of Educational Research, 95(6): 323-332.

Slavin, R. E. (2015). Cooperative learning method in elementary schools. Education, 43(1), 5-14.

Station, TX: Texas A\&M University.

Ukpokodu, N. (2002). Breaking through pre-service teachers' defensive dispositions in a multicultural education course: A reflective practice. Multicultural Education

Uwezo (2010). Are Our Children Learning Annual Learning Assessment Report. Nairobi: Uwezo Net. 